\title{
Garth Fowden
}

\section{Late Antiquity, Islam, and the First Millennium: A Eurasian perspective}

Since 1970, the period covered by Millennium: Jahrbuch zu Kultur und Geschichte des ersten Jahrtausends n.Chr. has seen two major historiographical shifts that are distinctive to it, and it alone, namely the rise of 'late Antiquity' and the flowering of early Islamic studies. There is no (well-founded) disagreement about roughly when and where Islam started; but late Antiquity's boundaries remain fluid. The Roman Empire's painful third-century transition from Principate to Dominate amidst war against Sasanids and Germans, and the sixth century's Justinianic consolidation of Christian East Rome, have often been attached to the core fourth and fifth centuries. A terminus c.600 is widely accepted, coinciding with Gregory the Great's reforming papacy, and the start of the last and most dangerous war between East Rome and the Sasanids, leading to the former's crushing defeat and the latter's annihilation by Muslim armies emerging unforeseen from Arabia after 629. Such a cataclysm does at first sight suggest the end of an epoch, considering also the narrowing of cultural horizon it imposed on the surviving East Roman rump, and the emergence of a new empire, the caliphate. Yet, given the symbolism ancient historians attach to the Persian Wars from Marathon to Plataea (490 - 79 BCE), and to Rome's wars with its eastern neighbour starting at Carrhae ( $53 \mathrm{BCE}$ ), it is perverse to exclude the last, most dramatic of these encounters, running from 603 to 628 , from the canonical narrative. Is it that adding those extra three decades would bring one so close to the Arab invasions that their Qur'anic inspiration would become impossible to ignore, and therefore unavoidable to study? And the caliphate these wars spawned: did it not, in many respects, perpetuate the earlier empires under new management, just as its religion, Islam, responded to the earlier scriptural monotheisms, Judaism and Christianity?

Nobody doubts the convenience and indeed necessity of historical periodizations. Nor the validity and usefulness of the well-established categories: (late) Antiquity, early Middle Ages, Byzantium/East Rome, Sasanid Iran, early Islam. It appears, though, that the boundary at c.600 is sufficiently porous, and the world of early Islam insufficiently explicable in terms of parthenogenesis within an 'Empty Hijāz', ${ }^{1}$ that there is a case to be made, alongside existing conventions, for exploiting

\footnotetext{
This article, written in December 2015, experiments with fresh perspectives on matters broached in Before and after Muhammad: The First Millennium refocused (Princeton 2014) [henceforth BAM]. My thanks to Johann Arnason (again) and Hartmut Leppin for their encouragement.
}

1 J. E. Montgomery, "The empty Hijāz," in id. (ed.), Arabic theology, Arabic philosophy. From the Many to the One: Essays in celebration of Richard M. Frank (Leuven 2006) 37-97. 
the possibilities for wider contextualization of Islam in time as well as space, that are offered by the emergent, major (re)periodization known neutrally as the First Millennium.

The First Millennium was brought to birth in the mid-1980s in the a-textual world of pre-Christian North European archaeology. More recently the British Museum has backed it in exhibitions adopting primarily material approaches to milieux that also yield a heavy freight of texts, such as the Silk Road and Egypt. ${ }^{2}$ Where the main evidence is hard-to-date objects rather than documents or texts, the round-figure neutrality of a periodization such as the First Millennium is unavoidable. But such neutrality (or imprecision) is also desirable for better-documented areas such as the one here under discussion, the purpose being firstly to make clear there are no absolute discontinuities in human affairs, and secondly to avoid the suspicion that one is periodizing in order to explain a particular historical event or process. This would both be inherently teleological, and to an excessive degree impose on history our view of what does or does not need to be explained, instead of leaving the evidence to throw up its own questions as well. In the First Millennium one can hardly ignore the establishment, governance, justification and expansion/defence of the Iranian, Roman and caliphal empires, or the rise and spread of religious movements especially Judaism, Christianity and Islam, or the relations between these empires and religions. The inception of relations between Iran and Rome, the career of the Christian prophet, and the first stirrings of the rabbinical movement, all occurred around the beginning of the First Millennium. The maturation of a recognizably classical form of Islam can be dated to the tenth and eleventh centuries. As symbolic markers of the beginning and end of the millennium we have Augustus who founded the Roman Empire, and Ibn Sīnā (Avicenna) who through a personal synthesis created the preconditions for reconciling philosophy with Muslim theology (kalām). To begin with a ruler and end with a thinker, far from being inconsistent, draws attention to the intertwining of empires and concepts throughout the First Millennium. It also avoids the impression that this periodization seeks to impose 'conceptual coherence' where there may have been none-although this danger, inherent in small-scale divisions ('The Age of Justinian/ Napoleon'), is less present in large-scale periodizations.

2 BAM 87-88; S. Whitfield (ed.), The Silk Road: Trade, travel, war and faith (Chicago 2004) (and cf. S. Kuwayama, Across the Hindukush of the First Millenium: A collection of the papers (Kyoto 2002); V. Hansen, The Silk Road: A new history with documents (New York 2017) 241); C. Fluck, G. Helmecke and E. R. O'Connell (eds), Egypt: Faith after the Pharaohs (London 2015), and cf. E. R. O'Connell (ed.), Egypt in the First Millennium AD: Perspectives from new fieldwork (Leuven 2014). I offer this and the following paragraph partly in response to the review of $B A M$ by L. Halevi, American historical review 120 (2015) 1838-40, invoking L. Besserman, 'The challenge of periodization: Old paradigms and new perspectives', in id. (ed.), The challenge of periodization: Old paradigms and new perspectives (New York 1996) 3-27, on Bloch, Collingwood and Foucault. 
My use of the term 'maturation' also demands comment. Some scholars resist biological metaphors ${ }^{3}$ because of a perceived anthropocentrism and teleology. But wines mature too. And history is the study of mankind in time, so the inappropriateness of biological metaphor is not self-evident. Given that each generation builds to some degree on the work of its predecessors, there may be a sense of purpose/telos too. I apply the term 'maturation' to cultural and conceptual systems, and what I intend is the development of such systems from their beginnings-often hard to pin down and differentiate from other systems-to a point where they acquire a recognizable identity, which may resemble how they appear today, assuming they have survived (which several First Millennium systems have). Maturation may or may not also imply continuity, another much debated term. In the case of Greek philosophy, Roman law or the scriptural monotheisms, we are talking about processes lasting many centuries, so an element of continuity can hardly be avoided. But at the same time, maturation often entails definition of 'orthodoxy' and exclusion of 'heresy', hence scission of communities and traditions, and initiation of new processes of maturation. Therefore, talking about maturation does not inevitably entail excessive continuitism. ${ }^{4}$ In the First Millennium, Islam is at certain levels continuous with the earlier scriptural monotheisms, and indeed the Qur'ān criticizes them for mistaking or obscuring the extent to which Islam was prophesied in their scriptures (5.19, 61.6). But it also breaks away, and embarks on its own process of growth and maturation, like the Church during its prolonged separation from the Synagogue. The whole interlinked, reactive process-the parallel evolution of Synagogue and Church, their separation and independent maturation, then the Qur'anic reaction and the maturation of Islam-will not be grasped within any chronological framework narrower than the First Millennium. But it must be grasped, if we would understand how we arrived where we are today.

Given, though, that the exclusion of the Arabian monotheism by students of late Antiquity is mirrored and reinforced by the later Muslim trope of jāhilìya, the Age of Ignorance that supposedly prevailed pre-Islam, ${ }^{5}$ we are alerted to the probability that our inclusive First Millennium will encounter resistance more ideological and entrenched than scholarly quibbling about periodization. As of 2015 there are those in the Muslim world who dynamite whole ancient cities because their excavation and preservation as 'cultural heritage', often at European or American initiative and in order to sustain artificial 'national' identities, rejects the example of idol-de-

\section{BAM 55 n. 18.}

4 On the controversy around this concept see B. Ward-Perkins, 'Continuitists, catastrophists, and the towns of post-Roman northern Italy', Papers of the British School at Rome 65 (1997) 157-76; C. Wickham, Framing the early Middle Ages: Europe and the Mediterranean 400-800 (Oxford 2005).

5 A. Neuwirth, Der Koran als Text der Spätantike: Ein Europäischer Zugang (Berlin 2010) 40 - 42, 20510 (in the Qur'ān itself, the word refers more to the moral state the scripture sought to reform than to an already superseded historical epoch). 
struction given by Abraham and Muhammad. ${ }^{6}$ As for Christianity, for most of the last millennium and a half its various strands have avoided open-minded engagement with Islam. Hardly surprising, then, that it is just when the Christian view of history begins to loosen its grip, at least on Western Europe, that we find Machiavelli taking a new, more generous tack.

Machiavelli exalted the armed prophet-prince, notably Moses, and admired the theocratic polities such men had founded. But while Moses was a legitimate object of praise in sixteenth-century Italy, the founder of the religion that sustained the Ottoman Empire was not. Hence Machiavelli's reticence about Muhammad himself. In his Discourses on Livy, though, he declares that Roman virtù passed to the Saracens and Turks as well as the Germans, for Islam 'did so many great things and seized so much of the world after it destroyed the East Roman Empire'. ${ }^{7}$ From this we may easily deduce how Machiavelli would have written about Muhammad. We may also note this early occurrence of the notion, central to the present essay, that there is more than one road out of Antiquity. By Hobbes's day it was possible to include Muhammad, alongside Numa Pompilius, among 'the first Founders, and Legislators of Common-wealths amongst the Gentiles'. ${ }^{8}$

The significance of such statements lies not just in a degree of open-mindedness about Muhammad, but also in the implication that, if he was not purely a prophet, he could not be dismissed purely as an impostor, as Christian polemicists always had (even if initially, in the seventh century, he had struck them more forcibly as warrior and lawgiver than as prophet $\left.{ }^{9}\right)$. Willingness to take Islam seriously, and to include it in historical narratives, more often than not sprang from a desire to undermine Christianity's claims. For an extended expression of this new, more calibrated if still polemical view of Islam, we may consider Edward Gibbon's The history of the decline and fall of the Roman Empire. Published between 1776, the year of the American Revolution, and 1788, the eve of the French Revolution, The decline and fall immediately captivated a public aware of the fragility of empire, and painted such a persuasive picture of the life and death of one empire that it came to be assumed that others would almost of necessity resemble it. Yet it is no exaggeration to say that the full force of Gibbon's history of empires has still not been felt. Almost all his readers

6 See 'Erasing the legacy of a ruined nation', Dabiq (Islamic State magazine: http://www.clar ionproject.org/news/islamic-state-isis-isil-propaganda-magazine-dabiq) 8 (Jumadah al-Akhirah 1436) $22-24$.

7 N. Machiavelli, Discorsi sopra la prima deca di Tito Livio ii. pref. 2 [trans. H. C. Mansfield and N. Tarcov, Discourses on Livy (Chicago 1996) 124]. Cf. R. Beiner, Civil religion: A dialogue in the history of political philosophy (Cambridge 2011) 29-33; P. M. Tommasino, 'Leer a Maquiavelo, traducir el Corán: Muhammad, príncipe y legislador en el Alcorano di Macometto (Venecia, 1547)', Al-Qanțara 33 (2012) 271-96, on a life of Muhammad in which the monk Sergius-Bahira exhorts him to dethrone Heraclius with arguments indebted to Machiavelli's vision of the armed prophet.

8 T. Hobbes, Leviathan (London 1651) ch. 12.

9 S. W. Anthony, 'Muhammad, the Keys to Paradise, and the Doctrina Iacobi: A late antique puzzle', Der Islam 91 (2014) 243-65, esp. 245-46, 263. 
agree with Norman Baynes's judgment that he is not worth the effort after 476, in other words from chapter 39 onwards. ${ }^{10}$ Only limited exceptions have been made, for instance for chapter 44 on Roman law, or chapter 50 on Muhammad. As for Gibbon's scathing treatment of Byzantium, it gained justified notoriety. But it was precisely this decision to carry the story of Rome's fall down to the Ottoman conquest of Constantinople in 1453 that necessitated more than just one chapter on Islam.

To justify neglecting Rome on the Tiber for alien, Greek Rome on the Bosporus, Gibbon argues that 'the fate of the Byzantine monarchy is passively connected with the most splendid and important revolutions which have changed the state of the world'. ${ }^{11}$ By this he primarily intends the rise of Islam-which he later calls 'one of the most memorable revolutions, which have impressed a new and lasting character on the nations of the globe, ${ }^{12}$-and the empires of the Arabs and then the Turks. In fact Gibbon treats at length, over seven whole chapters and sections of others, the empires of the Umayyads, Abbasids, Seljuks, Mongols and Ottomans. He takes care to reassure his readers that, while 'the excursive line may embrace the wilds of Arabia and Tartary', still 'the circle [of The decline and fall] will be ultimately reduced to the decreasing limit of the Roman monarchy'. ${ }^{13}$ The great work's coda offers a prospect of Old Rome as the Renaissance dawns. But this cannot disguise the radical historiographical innovation here being proposed: no less than abandonment of traditional Protestant as well as Catholic fixation on Europe's roots in Greece, Rome, Judaea and the Papacy; and its replacement by a vision of two main highways leading away from Antiquity, the well-trodden Latin Roman way, but also another starting from Greek Constantinople and leading to Arabic Damascus and Baghdad, whence one branch went to Toledo, Paris and Oxford, while others connected more directly to Cairo, Rayy, Konya and Istanbul, the capitals of what we may call the Islamic Commonwealth. ${ }^{14}$ Awareness of these two highways lies at the heart of the First Millennium periodization.

Gibbon lived at a time when educated Europeans might be knowledgeable about Asia and appreciate its historical originality and sometimes even its contemporary vigour, and just before the industrial, military and colonial expansion of the nineteenth century-and the racism stoked by the Greek uprising of 1821 and its Turkophobe apologists-encouraged an arrogance that made it hard to take Asia seriously any more. ${ }^{15}$ Perhaps this is what made the vision delineated in Gibbon's last three

10 G. Fowden, 'Gibbon on Islam', English historical review 131 (2016) 261-292.

11 E. Gibbon, The history of the decline and fall of the Roman Empire 48: 3.25; cf. 69: 3.978 [ed. D. Womersley, London 1994; henceforth DF: references consist of the chapter number followed by volume and page in Womersley's edition].

12 DF 50: 3.151.

13 DF 48: 3.25; cf. 48: 3.26, 51: 3.237.

14 On the Islamic Commonwealth see BAM 114-16.

15 J. Osterhammel, Die Entzauberung Asiens: Europa und die asiatischen Reiche im 18. Jahrhundert (Munich 2010²) 12-13, 20-21, 35-7, 52-3, 55, 376-82. 
volumes so unappealing to his otherwise admiring posterity. The attitude persists today, intensified by specifically anti-Muslim hysteria. Even Gibbon's most assiduous current student, John Pocock, in his six-volume Barbarism and religion completed in 2015, accepts the conventional judgment that The decline and fall climaxes with the collapse of the Roman Empire in the West and the end of its 'grand narrative', while he regards the three 1788 volumes as 'radically different histories' lacking a grand narrative, and has almost nothing to say about them. ${ }^{16}$ Pocock leaves untold half the story in terms of Gibbon's three volumes out of six, or four fifths of it chronologically.

Given the progress of historical research, but also Gibbon's uncritical approach to some of his main sources, he was for generations read primarily as a literary monument; while thanks in recent decades to Arnaldo Momigliano and John Pocock, he has also become an important chapter in the fashionable history of historiography. But his treatment of Islam both as part of a continuous narrative starting in Antonine Rome (and which in later years he felt ought to have begun at the death of Augustus ${ }^{17}$ ), and as a necessary accompaniment to the history of East Rome and emergent Latin Europe (through the Crusades), identifies him as a forerunner of the First Millennium periodization here proposed. Gibbon can still help generate new historical insights, provided the full extent of his history is taken into account. Reading only the truncated Decline and fall of the first thirty-eight chapters, plus the 'General observations on the fall of the Roman Empire in the West', merely flatters the Eurocentric prejudices of those who see Rome's fall to Alaric's Visigoths in 410 as the end of Antiquity. Taking on board the full Decline and fall of seventy-one chapters initiates one into a more polycentric, Eurasian view of Antiquity and the Middle Ages, right down to 1453.

Here, though, we shall modestly confine ourselves to the First Millennium, viewed primarily as a period of crucial conceptual maturations in politics, religion and the sciences. The idea of Rome, incarnated by Augustus and Christianized by Constantine, is paralleled by the Sasanid Empire with its Iranian, Mazdean identity and its aspiration to restore the glories of the Achaemenids. The rabbinic phase in Judaism, sparked by Rome's destruction of Jerusalem in $70 \mathrm{CE}$, unfolds on both Roman and Sasanid territory, as does (with a greater inclination towards Rome) the patristic efflorescence of Christianity. Outside the sphere of the scriptural monotheisms, we observe the Justinianic codification of Roman law, the Galenic synthesis of Greek (Hippocratic) medicine, and the harmonization of Plato and Aristotle in the philosophical schools especially of fifth- to sixth-century Alexandria. Then, in the crucial seventh century, the revelation of the Qur'ān sparks the creation of a new em-

16 J. G. A. Pocock, Barbarism and religion (Cambridge 1999-2015) 5.385-6, and cf. 374; 6.4-9, 19, 335, 339, 371, 374, 415-16, 438, 455, 492, 501-9.

17 See his marginal annotation, ed. Womersley, DF 3.1093. 
pire, the caliphate, and its 'Islamicate' culture, open to Jews and Christians as well, sometimes strikingly original, other times indebted to several or all of these earlier developments. We have, then, a field of empires traversed by streams of concepts, whose interactions as well as independent identities the historian must map.

The engagement that most characterized the First Millennium on the imperial stage, notably that between Iran and Rome, had not been without precedent. The wars of the Persians and Greeks had their sequel in Alexander's conquest of the Achaemenid Empire and his burning the royal palace at Persepolis to revenge-it was said-Xerxes's devastation of Athens. Alexander provoked and inspired rulers from West to East for age after age to come. Yet Rome had no sustained contact with the Arsacid or 'Parthian' Empire, which gradually supplanted Alexander's Seleucid heirs, until Pompey annexed Syria as a province, rather than a client state, in 64 BCE. His triumviral colleague Crassus launched an ill-conceived invasion of Rome's new neighbour in 53, and received a well-deserved comeuppance at Carrhae. That could have taught the Romans a thing or two about the pitfalls of Mesopotamian campaigning, of which they did enough, occasionally with catastrophic results, over the next seven centuries. Yet nobody took the lesson to heart until in 624-27 Heraclius, who was of Armenian ancestry, delivered a knockout blow to Khusrau II in his heartlands of North-West Iran and Mesopotamia via the mountain route (which the Armenian ruler of the day had told Crassus to take).

This is not the place to delve into relations between Rome and Iran, the former well-documented, and paradigmatic for theorists of empire, the latter almost unknown save from Roman or Arabic sources, and so un-paradigmatic that comparative historians of empire prefer to pair Rome with China (yet admit that direct contact was so negligible that comparison works better via intermediaries, such as the Kushans for trade or the Huns for diplomacy and war ${ }^{18}$-but not Iran!). Yet the inability of either Iran or Rome to deliver that knockout until it was too late underlines the balance of power between 'the world's two eyes'. ${ }^{19}$ There was a sense that they accounted for what mattered in the oikoumene, while what lay beyond was unknown for good reason. Hence the evolution of the Alexander legend, which embroidered the Macedonian's conquests in the East but radically innovated in the West by taking him to Ocean's edge. The Qur'ān has the prophet-king Dhū 'l-Qarnayn (who bears striking resemblance to Alexander) visit both the rising-place and the setting-place of the sun. ${ }^{20}$ Surely this, and anything else they could gather about Alexander, will have set a mental map for the Umayyad caliphs and generals who accomplished the bulk of the Muslim conquests from the Oxus and Indus to the Atlantic coasts of Morocco and Spain. Those conquests effected what nobody before had achieved even if some dreamed of it, namely a single empire embracing the entire Sasanid state and

18 H. J. Kim, 'Ancient history and the Classics from a comparative perspective: China and the GraecoRoman world', Ancient West and East 14 (2015) 258-66.

19 BAM 104 n. 51.

20 Qur'ān 18.83-91. 
Rome's Levantine, North African and Iberian provinces, plus the vast peninsula of Arabia which neither Iran nor Rome had durably penetrated. The Mediterranean was now, it is true, divided for the first time since Augustus. But its Christian northern shore was exposed to constant raiding and occasional colonization by Arab 'pirates', culminating in the ninth century. ${ }^{21}$ The Red Sea and the Persian Gulf were under Muslim control, facilitating access to India and ultimately China. And the network of overland 'Silk Roads' between China and the Levant was at last unimpeded by Sasanid levies on trade.

This calls to mind the 'circulatory', adaptive and self-recreating character of Asian/Eurasian civilizations contrasted by Prasenjit Duara to the linear, bounded, less trans-local flows that characterize the European world, and especially their 'tunneled' nationalist historiographies. ${ }^{22}$ Although there have been more than enough European and Mediterranean trans-local flows to make Duara's contrast seem rather crude, he is right to draw attention in this context to the role of Buddhism, whose potential for imbuing the vast, almost sub-continental Mauryan Empire with social cohesiveness was already in the mid-third century BCE recognized by King Piyadasi, identified by modern scholarship (not so convincingly) with the mighty Ashoka of later Buddhist legend. ${ }^{23}$ These legends, and much else we today see as classically Buddhist, in fact date from the middle of the First Millennium and later. But very recently the caves round Bamiyan and elsewhere in Gandhara have yielded abundant sutras (scriptural texts) and abhidharma (exegetical works) written on birch bark, which push the history of Buddhist literature back to the first and second centuries CE. ${ }^{24}$ Given that Muslim invaders terminally loosened Buddhism's grip on India and Central Asia by the ninth century, this makes its documentable history in its historic homelands very much a phenomenon of the First Millennium, except for some archaeological evidence for monastic settlements from the third century BCE onwards (and the remarkable but chronologically outlying sixth-century discoveries at Lumbini in 2013). ${ }^{25}$

Buddhism's spread into Central Asia, China and Eastern Iran was hugely facilitated from the first century CE by the Kushan Empire, which stretched from Benares to the Middle Oxus including the Sogdian crossroads of Central Asia, and whose influence touched Kashgar at the western end of the Tarim Basin on the highway to

21 C. Picard, La mer des califes: Une histoire de la Méditerranée musulmane (VII ${ }^{\mathrm{e}}$-XII ${ }^{\mathrm{e}}$ siècle) (Paris 2015) 289-332.

22 P. Duara, The crisis of global modernity: Asian traditions and a sustainable future (Cambridge 2015) 53-90.

23 H. Tieken, 'The role of the so-called Aśoka inscriptions in the attempt to date the Buddha', Rivista di studi sudasiatici 1 (2006) 69-88.

24 P. Harrison and J.-U. Hartmann (eds), From birch bark to digital data: Recent advances in Buddhist manuscript research (Vienna 2014).

25 L. Fogelin, An archaeological history of Indian Buddhism (New York 2015). 
China. ${ }^{26}$ The first Kushan king, Kujula Kadphises (c. 30-80 CE), aped Augustus's coinage, adding legends in Greek and Kharosthi, while he fostered export of silk to Rome through his Indian Ocean ports. There are records of Indian embassies to Augustus and several second-century emperors. The greatest Kushan ruler was 'Great King, King of Kings, Son of God' Kanishka I (serially re-dated, most recently to 155 - c.179 ${ }^{27}$ ), whose patronage of Buddhism seems to have been modelled on Piyadasi/'Ashoka'. But the rise of the Sasanids from the 220s undermined the Kushans. From c.320 the Gupta Empire assumed some of its territories and dominated large areas of the subcontinent until the mid-sixth century Hun invasions.

Thereafter, for the rest of the First Millennium, India produced no comparable imperial regime. It did though play host to a cultural evolution that roughly coincided with the First Millennium and has recently attracted scholarly debate. ${ }^{28}$ From the mid-second century CE onward, Buddhism adopted Sanskrit in place of vernaculars such as Gandhari. This flouted the Buddha's own example; but it is part of a wider story about the privileging of this previously sacred language for secular literary expression as well, and for the rhetorical proclamation of political power (though not in administration and everyday life) across a vast zone from Afghanistan to Java, throughout the rest of the First Millennium. Sanskrit was ideal for this purpose because (despite its many local scripts) it was not identified with particular places or peoples, except for the Brahman exponents of Vedism, whose influence also favoured Sanskritization. Sanskrit was profoundly expressive, and was governed by rules so coherent, uniform and stable that mastery of grammar came to be an attribute of kingliness. Comparing this development to the story of Latin as the learned, prestige lingua franca of the Roman West in the same period, both under the empire and in the early Middle Ages, Sheldon Pollock has highlighted the role language may play in defining cultural worlds, even when they embrace several religions simultaneously or sequentially, or-as in South Asia-a plurality of states all claiming to be 'universal'. The similarity extends to both languages' gradual loss of cultural dominance from the ninth century onward thanks to the emergence of vernaculars, something paralleled in the Greek world (the languages of Oriental and Slavic Christianity) but not in the Arabic sphere, despite its huge extent. To this process of vernacularization there were political parallels too, notably in the Latin West (Germanic successor states) and the caliphate (Abbasid successor states), less so in South Asia where no single empire had ever emerged.

26 J. Lerner, 'Regional study: Baktria-the crossroads of ancient Eurasia', in C. Benjamin (ed.), The Cambridge world history 4: A world with states, empires, and networks, 1200 BCE-900 CE (Cambridge 2015) 313-18.

27 K.-H. Golzio, 'Zur Datierung des Kuṣānā-Königs Kanișka I.', in D. Dimitrov, M. Hahn and R. Steiner (eds), Bauddhasāhityastabakāvalī: Essays and studies on Buddhist Sanskrit literature dedicated to Claus Vogel by colleagues, students and friends (Marburg 2008) 79-91.

28 S. Pollock, The language of the gods in the world of men: Sanskrit, culture, and power in premodern India (Berkeley 2006), esp. 59-74, 253-58, 259-80. 
Pollock's 'Sanskrit cosmopolis' is a phenomenon of South and South-East Asia. To the north and west, in China, Tibet, Central Asia and Iran, Buddhism spread and took Sanskrit with it. It did not add these regions to the Sanskrit-dominated core; nor did it confine itself to Sanskrit. Instead, it was here that what has been called 'Buddhist late Antiquity ${ }^{29}$ witnessed unexpected interactions between Indian and other, alien systems of thought emanating from the East (the Chinese and Tibetan versions of Buddhism are well known) but also from the West: Church of the East ('Nestorian') Christianity, Manicheism, and Islam. It is under the aegis of Islam, and specifically in early Abbasid Baghdad, that we observe a striking encounter between Sanskrit scholarship propagated by men of Buddhist culture, and the Greek tradition.

During the reign of the Umayyad Caliph Hishām (724-43) was completed the conquest of the only flourishing Buddhist (and therefore to some degree Sanskritic) region the Arabs ever colonized, namely Bactria/Tocharistan and the city of Balkh in what we call northern Afghanistan, athwart the highway from India into Iran or across the Pamirs to China. A family known as the Barmakids controlled a famous, wealthy Buddhist pilgrimage-monastery near Balkh, the Nawbahar. ${ }^{30}$ The last Barmak had studied Indian astrology, medicine and philosophy in Kashmir, in the early years of the eighth century; but after Balkh fell in 725 he was taken hostage to Rusāfa in Syria by Hishām, and converted to Islam. His son Khālid, who had presumably grown up in Balkh as a Bactrian-speaking Buddhist, joined the Abbasid revolt against the Umayyads. He held high office under the first two Abbasid caliphs; his son Yahyā was tutor and eventually vizier to Hārūn al-Rashīd; and under the same caliph's rule Yahyaā's two sons reached such a dizzy pinnacle of wealth and power that there was nowhere else to go but an abrupt fall from grace in 803. But by then the Barmakids, who no doubt found the early Abbasid milieu slightly uncouth compared to Balkh, had had several decades to introduce their patrons, and the newly founded capital Baghdad, to the ancient, sophisticated Indian culture that was their birthright. Yahyā brought Indian doctors to work in the hospital he built. He encouraged translation of Indian medical books, and sent a mission to gather Indian medicinal plants. He fostered interest in Indian religion (possibly including Buddhism) and philosophy, political science and rhetoric, no doubt alongside the astronomy and astrology Arabs had already studied before his day. Since some of the same works, presumably the basic handbooks used in India and specifically in Kashmir, were translated into Tibetan as well between the late eighth and eleventh centuries, we can see Kashmir, Balkh, Tibet and Baghdad as stops on an

29 A. von Le Coq, Die buddhistische Spätantike in Mittelasien (Berlin 1922-33).

30 On the Barmakids see K. van Bladel, 'The Bactrian background of the Barmakids', in A. Akasoy, C. Burnett and R. Yoeni-Tlalim (eds), Islam and Tibet-Interactions along the musk routes (Farnham 2011) 43-88; id., 'Barmakids', in M. Gaborieau and others (eds), The encyclopaedia of Islam three (Leiden 2007- ), http://referenceworks.brillonline.com/browse/encyclopaedia-of-islam-3, with further bibliography. 
Asian, Buddhist-mediated knowledge-circuit of just the sort Prasenjit Duara discusses.

Later Arabic scholars such as Jāḥiz, Ibn al-Nadīm and Bīrūnī treated Indian science with deep respect, while the Pañcatantra, a mirror for princes masquerading as a collection of moralizing animal stories, became widely popular in Arabic under the title Kalila wa-Dimna. But in the long run Indian learning lost ground to the Greeks. Galenic medicine and Ptolemaic astronomy were already so deeply rooted in the Syriac world, whose scholars then conveyed them into Arabic, that Indian medicine and astronomy gained relatively little purchase. Aristotelian logic proved more congenial than Indian to defenders of Qur'anic truth against Christian polemic. Nevertheless the competition between Indian and Greek scholarship in Baghdad allows us to reconnect, after this Asian excursus in the spirit of Gibbon, with the question posed at the outset, namely the relationship between Islam and the more familiar Mediterranean and Levantine late Antiquity of Sasanids, East Romans, and the scriptural monotheisms.

To pursue this eminently comparative enquiry, we configure data and narratives so as to detect commonalities and differences. We so dispose our evidence as not to impose harmony and coherence, but at least to suggest comparability. Otherwise, no such cross-cultural periodization could work. But to keep in mind the lived reality of the times in question, we must ask whether either our periodization itself, or this type of comparison, formed part of the mental toolkit of contemporaries. ${ }^{31}$ Depending on the answers, it may be possible to locate an advantageous standpoint to survey the First Millennium we are interested in. For obvious reasons of chronological coverage, that vantage point will be located toward the end of our period.

It is possible to find tenth- or early eleventh-century narratives that claim to be historical and employ a First Millennium framework. A striking example is the account left by, among others, the Muslim philosopher Fārābī (d. 948)-who spent his career in Baghdad, Syria and Egypt-of the transmission of Aristotle's teachings and the Aristotelian curriculum from Alexandria, where Augustus undertook a thorough inventory of the corpus Aristotelicum, via Umayyad Syria to the Baghdad of his own day. ${ }^{32}$ Rather similar to this is the letter written in 987 by the leading Baghdadi rabbinical authority (gaon) Sherira ben Hanina, tracing the formation of the Mishnah and the Talmud in the aftermath of the destruction of the Jerusalem temple in $70 \mathrm{CE}$,

31 As regards the periodization issue cf., at greater length, G. Fowden, 'War das erste Jahrtausend eine bedeutsame Periodisierung für die Zeitgenossen?', in N. Schmidt, N. K. Schmid and A. Neuwirth (eds), Denkraum Spätantike: Reflexionen von Antiken im Umfeld des Koran (Wiesbaden 2016) 499-531. 32 D. Gutas, 'The 'Alexandria to Baghdad' complex of narratives: A contribution to the study of philosophical and medical historiography among the Arabs', Documenti e studi sulla tradizione filosofica medievale 10 (1999), 155-93; cf. id., Greek thought, Arabic culture: The Graeco-Arabic translation movement in Baghdad and early 'Abbāsid society (2nd-4th/8th-10th centuries) (London 1998) 90 - 95. 
and the succession of Babylonian scholarchs down to his day. ${ }^{33}$ Sherira's account is more factually credible than Fārābī's; but both focus on a specific intellectual tradition in order to demonstrate that a narrowly defined succession of transmitters delivered orthodox doctrine safely to the man who just so happens to be the author. A few decades later the Church of the East bishop of Nisibis, Elias bar Shenaya (d. 1046), wrote a chronicle that adopted an immensely wider frame-the empires of Iran and Rome, and the caliphate, and by implication both Christianity and Islam, from the time of Abgar of Edessa, Tiberius, Pontius Pilate and Christ down to 1018. This is the nearest we get to a contemporary history of the First Millennium, but with a firmly institutional rather than doctrinal focus: empires and episcopal sees. Elias's models were, among others, the Arabic historian Țabarī (d. 923) and the ecclesiastical historian and chronicler Eusebius of Caesarea (d. 339). But Tabarī, being an Iranian as well as a Muslim, had no interest in Rome and very little in the western lands of the caliphate; while Eusebius and all his continuators down to Jacob of Edessa (d. 708), whom Elias also used, lived too early to have a sense of the First Millennium or-of course-for more than passing cognizance of Islam.

From these three distinctive perspectives on the First Millennium, derived from each of the scriptural monotheisms, it is predictably apparent that the vantage point from which to survey it will be Abbasid Baghdad, or more generally Mesopotamia. Fārābī and Sherira lived in the capital, while Elias of Nisibis was familiar with Baghdad and its doings, notably its ecclesiastical affairs. ${ }^{34}$ We shall return to Baghdad later.

Absent from these texts, though, is an interest in comparison. This is true of Fārābī and Sherira by definition, and of Elias because of the brevity and factuality the chronicle format imposes. Systematic comparison was anyway not much favoured in the First Millennium, except in polemic where the outcome was predetermined and the method and materials therefore unappealing to the historian. Nevertheless two texts are worth invoking here, one for being so unusually impartial that it is hard to divine the allegiance, far less the identity, of its author, so that it illustrates rather well the possibilities of comparative scholarship in the First Millennium; and the other because its comparisons, although polemical, set the tone for the last phase of the First Millennium.

If the latter text is obviously the Qur'ān, the former is a little-known work, probably from the 390s, which its manuscripts call Lex Dei quam Dominus praecepit ad Moysen, implying a Jewish or possibly Christian standpoint, while from the late 1500s scholars chose to emphasize its comparative aspect by renaming it Collatio

33 Sherira ben Hianina Gaon, Iggeret [ed. (with English translation) N. D. Rabinowich, The Iggeres of Rav Sherira Gaon (Jerusalem 1988); German translation M. Schlüter, Auf welche Weise wurde die Mishna geschrieben? Das Antwortschreiben des Rav Sherira Gaon (Tübingen 1993)].

34 E.g. L.J. Delaporte, La Chronographie d’Élie Bar-Šinaya, Métropolitain de Nisibe (Paris 1910) II - III. 
legum Mosaicarum et Romanarum. ${ }^{35}$ Taking cues from the Decalogue, the anonymous author sets out parallel quotations from the Pentateuch and Roman legal sources, highlighting their essential unity, not without tweaking them a bit. At this period, a person eager to demonstrate the coherence of Mosaic and Roman law in Latin was most likely a Christian; but for present purposes what is even more interesting is his ability to juxtapose and compare sources from two totally alien traditions without evident parti pris and in full awareness that the cultural synthesis under way in his own times was bound to depend on both. One of the imperial rescripts he includes is Diocletian's of 302 against the 'Persian poison' of Manicheism that was infecting Rome's subjects at that time, but also (it seems) against Mazdaism. ${ }^{36}$ This adds further dimensions to his comparative enterprise.

Rome, if we locate the Collatio there or possibly elsewhere in Italy, was a fine centre from which to undertake cultural comparisons in the late fourth century, though not for much longer, especially given the neglect of Greek. By contrast, the Qur'ān's origin in the Hijāz is peripheral to Rome and Iran alike. While that location is partly responsible for the idiosyncrasies in the Qur'anic view of Judaism and Christianity, it must also explain how its author acquired critical distance from both, as well as observing the Great War between Iran and Rome from a safe if not impartial position (30.1-5). No subject of East Rome would have publicly proclaimed such scepticism of Christianity, while no inquisitive subject of the Sasanids would have remained so idiosyncratically informed about either of the scriptural monotheisms, and their numerous and loquacious adherents.

Here is not the place to examine in detail the Qur'ān's take on Judaism and Christianity. Suffice it to say that the 'straight path' (al-șirāt al-mustaqīm) sura 1 proclaims, 'the path of those You have blessed, not of those against whom there is anger, nor of those who go astray', together with the scripture's emphasis on the long succession of prophets including Jesus, and 'sealed' (33.40) by Muhammad, places it, via a process of comparison, at the culminating point of scriptural monotheist history. In other words, comparison leads to a general sense of periodization too, given also that the awareness of kerygmatic culmination means that we must also be at the beginning of a new (albeit final and possibly brief) phase when mankind gets its chance to absorb the pure new Arabic scripture before the Eschaton. According to this theological view of things, then, the new Prophet and his revelation are the pivot of human history.

So much for the contemporary, First Millennium viewpoint. But what about the modern and secular-or at least non-Muslim-historian's view of the same landscape? We have seen that the notion of more than one 'straight path' out of Antiquity is already there in Gibbon, however minimal its impact on his posterity. We now need

35 R. M. Frakes, Compiling the Collatio legum Mosaicarum et Romanarum in late Antiquity (Oxford 2011).

36 Collatio [ed. Frakes] 15.3: 'uel ad doctrinam Persarum'. 
to consider more seriously the various First Millennium dynamics that offer support to Gibbon's argument, and alternatives to the more traditional narrative-appealing to Catholics but not radically overturned by Protestant scholars, who were likewise Latin-speaking Europeans-that concentrated on the Roman Empire in the West ceding its prestige and some of its power to the Papacy, whose complicated relations with emergent German imperium in the North provided the stuff of history until the dawn of the Renaissance, also partly fostered by the Popes. Taking the other, Oriental route out of Antiquity, we shall again find ourselves drawn towards Baghdad, 'the metropolis of Islam'. ${ }^{37}$

I have already alluded in passing to the Eurocentric notion, for which Gibbon's support has falsely been claimed, that Antiquity ended in 410 or 476. Leaving aside the possibility that 'Antiquity' may not have died in one night, it is evident that these dates meant little to the Greek East, let alone Sasanid Iran. Yet there are other possible dates that do involve the East: not just 600, discussed above, but also 529, when Justinian banned the teaching of law and philosophy at Athens ${ }^{38}$-though not in other centres such as Beirut or Alexandria, which detracts somewhat from the terminal nature of the event. The date of the Council of Chalcedon, 451, is popular among patrists, who nearly all belong to Churches that accept that council, and certainly not to the Oriental traditions, on which see further below. Rabbinicists draw attention to the period around 500 when the Babylonian Talmud is said to have 'closed', while conceding that it went on evolving into the eighth century. And although the Roman Empire continued in the East until Trebizond fell in 1461, the habit of re-baptizing it 'Byzantine', from the seventh century if not earlier, conveys an impression of novelty and discontinuity as well as alienation, given the word's connotations (here Gibbon is genuinely to blame). It is hard then to escape the impression that, even without invoking Islam, something old died and something else, perhaps not entirely agreeable, came into being between 400 and 600, or a little later.

Yet it is possible to view the fifth and sixth centuries in a more constructive and developmental light. For example, the philosophical schools of Athens were associated with Platonism; and while there were Christian Platonists too, the Athenian Platonists were thought excessively attached to the old pantheon. At Alexandria, though, a different approach to ancient Greek philosophy prevailed. As already mentioned, it was based on the view, propounded by Plotinus's pupil and editor Porphyry (d.c. 303), that the way to deal with apparent conflicts in the teachings of Plato and Aristotle was to 'harmonize' them. In the sixth century, especially in the work of John Philoponus (d.c. 570), we see an attempt to harmonize this tradition, in its turn, with the Christian scriptures. Although evidence for the Alexandrian schools

37 Al-Muqaddasī, Ahsan al-taqāsīm fī ma'rifat al-aqālìm 119 [ed. M. J. de Goeje (Leiden 1877, corrected reprint 1906); tr. B. Collins, Al-Muqaddasī, The best divisions for knowledge of the regions (Reading 1994)].

38 John Malalas, Chronographia [ed. I. Thurn (Berlin 2000)] 18.47. 
fades in the seventh century, Syrian Christian graduates such as Sergius of Resh'aina (d. 536) had long since taken the Alexandrian curriculum home and started to expound in Syriac (in Sergius's case), and eventually to translate (as knowledge of Greek dwindled or philosophical tastes spread), its more elementary parts, especially Aristotle's logical works.

Syriac Aristotelianism was, then, an outflow from the philosophical curriculum of Alexandria, which was a self-justifying course of intellectual training equally valid for worshippers of the old gods, or the Christian God-or eventually the Muslim God, the God of Fārābì for example. If Christians wanted to avoid direct contact with Plato and his pagan interpreters, however harmonized with Aristotle, they might substitute the mystical theology of 'Pseudo-Dionysius the Areopagite' (fl.c. 500), a Christian student or reader of the Platonist philosopher Proclus of Athens (d. 485) done into Syriac by that same Sergius of Resh'aina. ${ }^{39}$ Therefore, no essential aspect of either the Christian or the philosophical strands of First Millennium culture-not even the harmonization of Plato and Aristotle-was inaccessible to sixth- or seventh-century Syrian Christians, even if they knew only Syriac. But weaving them together was harder. Ever since the Arian debates in the fourth century, Greek philosophical terminology, Aristotelian logic in particular, had insinuated itself, not without controversy, into Christian doctrinal formulation in the Greek-speaking world. The Christological dissensions of the fifth century, especially after Chalcedon, generated another huge body of philosophically tinged polemic, increasingly in Syriac too. The authority of scripture and the fathers remained pre-eminent, but philosophical language was often invoked, and some saw Aristotle behind every heretic. ${ }^{40}$

Nevertheless, despite the bitter divisions, including the emergence of a parallel, anti-Chalcedonian or 'miaphysite' ecclesiastical hierarchy, the Church could still aspire to generate consensual solutions and restore its own unity. Sergius, named for Syria's favourite martyr saint but having renounced his parents' anti-Chalcedonianism, ascended the patriarchal throne of Constantinople in the same year Heraclius took the imperial throne (610), and served until he died in 638. He undertook to bridge the divide between the adherents of the one and the two natures in Christ with his first 'monenergist', subsequently 'monothelite' doctrine of two natures

39 J. W. Watt, 'The Syriac Aristotle between Alexandria and Baghdad', Late antique religion and culture 7 (2013) 26-50.

40 E.g. Anastasius of Sinai (d. after 701), Hodegos 6.2, 100 [ed. K.-H. Uthemann (Turnhout 1981)]. Watt, art. cit. (n. 39), and 'The Syriac Aristotelian tradition and the Syro-Arabic Baghdad philosophers', in D. Janos (ed.), Ideas in motion in Baghdad and beyond: Philosophical and theological exchanges between Christians and Muslims in the third/ninth and fourth/tenth centuries (Leiden 2016) 7-43, along with D. King, 'Why were the Syrians interested in Greek philosophy?', in P. Wood (ed.), History and identity in the late antique Near East (New York 2013) 61-81, and 'Logic in the service of ancient Eastern Christianity: An explanation of motives', Archiv für Geschichte der Philosophie 97 (2015) 1-33, doubt Syriac theologians deployed much Aristotelian logic in dogmatic polemic before the ninth century, but concede there was from Sergius onward a distinctive Syriac Christian philosophy in which Aristotle prepared one for the theology of Dionysius. 
(for adherents of Chalcedon) but one natural activity or will (for its opponents)-an eminently philosophical formulation. ${ }^{41}$ After prolonged debate, including an attempt to silence Monothelitism's most philosophically sophisticated opponent Maximus the Confessor (d. 662) by amputating his tongue and right hand, monothelitism was rejected as heresy, albeit not definitively until 680-81. 'And while the Church...was being troubled thus by emperors and impious priests', wrote the ninth-century Greek chronicler Theophanes, 'Amalek rose up in the desert, smiting us, the people of Christ, and there occurred the first terrible downfall of the Roman army...' Before long, another theology of unity, far more radical but framed in explicit response to the disputatiousness of Christians and their corruption of the scriptures, was established in the lands where Sergius had grown up, and where Muhammad had no doubt formed some of the impressions of Christianity expressed in the Qur'anic revelation delivered during just the same years Sergius served as patriarch. Islam too was catalogued by some contemporary observers as another in the long line of Christian heresies. It was more than that, and enjoyed the crucial advantage of being based outside the empire, beyond Constantinople's reach. But the comparison with Sergius's monothelitism does highlight the Church's attempts to grapple with the same problems to which the Qur'ān offered a less philosophically informed response-and perhaps, just for that reason, a more persuasive one.

In the history of Christian doctrine, then, the year 600 is no more than 451 a caesura; and the Qur'ān may be seen, at one level, as continuing (rather than interrupting or abandoning) these debates. Recent scholarship demonstrates continued interaction between Syrian Christianity and early Islam. ${ }^{42}$ For example, Syriac polemical texts provided a model for early Muslim apologetics in Arabic; while the Greek theological tradition was not formally summed up until an Umayyad subject, John of Damascus (d. 740s), compiled his Fount of knowledge in conscious response to the Qur'ān's strictures on Christianity. John's Arabophone successors increasingly adopted Qur'anic terminology, especially when debating with Muslims. Theodore Abū Qurra (c. 755-c.830), for example, a Chalcedonian bishop of Ḥarrān (Carrhae), and well versed in Greek philosophy, expressed even such distinctively Christian doctrines as Trinitarianism in the concepts and language of the Qur'ān and Muslim apologetic theology (kalām), as no doubt when he disputed with Muslim scholars before

41 Theophanes, Chronicle AM 6121 (628/29 CE) [ed. C. De Boor (Leipzig 1883) 329-32; tr. C. Mango and R. Scott, The Chronicle of Theophanes the Confessor (1997) 460-62]; J. L. van Dieten, Geschichte der Patriarchen von Sergios I. bis Johannes VI. (610-715) (Amsterdam 1972) 1-56; C. Lange, Mia Energeia: Untersuchungen zur Einigungspolitik des Kaisers Heraclius und des Patriarchen Sergius von Constantinopel (Tübingen 2012).

42 J. Tannous, 'Between Christology and kalām? The life and letters of George, bishop of the Arab tribes', in G. A. Kiraz (ed.), Malphono w-rabo d-malphono: Studies in honor of Sebastian P. Brock (Piscataway, N.J. 2008) 707-13 (Syriac and Arabic apologetic); S. H. Griffith, The Church in the shadow of the Mosque: Christians and Muslims in the world of Islam (Princeton 2008) 40 - 42 (John of Damascus); 53-57, 60-63, 93-99 (Theodore Abū Qurra). 
the Caliph Ma'mūn during the latter's visit to Harrān in 829. Note the attention Theodore and others like him gave to those parts of the Old Testament-the Prophets and Psalms-to which the Qur'ān also frequently alludes. Given the durability of Islam, and the alienation brought about by the failure of almost all the other Christian traditions to engage with it, in both East and West, it is perverse to ignore this evidence of patristic Arabic Christianity's adaptability. It is germane to the periodization issue too, since it makes the full maturation of patristics in the light of Islam virtually coterminous with the First Millennium. The recognition by mainstream patristics of Muslim-influenced Arabic patristics as an authentic mode of Christian expression would be an example of late Antiquity taking on new dimensions when viewed through the First Millennium lens from the multicultural and multiconfessional perspective of the caliphate. And it is germane also to the present-day dialogue of religions, and the possibility of building on what Judaism, Christianity and Islam hold in common, most of all the oneness of God, mediated to mankind (but also tragically obscured) through the doctrines of the Trinity and the Incarnation.

From these Syriac and Arabophone milieux we have just glanced at came the translators who, in early Abbasid Baghdad, rendered vast tracts of Greek medicine especially Galen, and Greek philosophy especially Aristotle, either directly into Arabic or indirectly via Syriac. The Arabic translation movement from Greek was one of the most fertilizing cultural achievements of the First Millennium. It evoked sceptical reactions among adepts of the Qur'anic sciences especially grammar; and they were the majority of the educated class. ${ }^{43}$ But for an influential minority, the Greek texts made possible a flowering of Arabic learning and science and even Muslim theology (see below on Ibn Sīnā), which has never lacked admirers among students of the Latin renaissance it provoked (after a further phase of translation) from the twelfth century onward, but which also had its own autonomous history with many later chapters in the Fatimid, Seljuk, Mongol, Safavid, Mughal, Ottoman and modern worlds, all way-stations along the second highway out of Antiquity.

To conclude this glance at the First Millennium stream of concepts as it swirls across the weir, or rather dam, scholars have erected at the c.600 mark, it deserves mention that recent research highlights how Jewish scholars too launched themselves forth on the great ocean of Arabic. ${ }^{44}$ The establishment of the caliphate united most of the world's Jews under one government. It offered the rabbinical elite a chance to impose the moral hegemony of their Talmudic orthodoxy from Central Asia to the setting sun. To the Babylonian academies of Pumbedita and Sūra', which moved to Baghdad in the course of the later ninth and tenth centuries, Jews from all over did indeed appeal on disputed questions of belief and practice. But just as resistances emerged to the assertive new political and religious elites of the Muslim world, so by the late ninth century the rabbis too confronted a rejectionist

43 BAM 208-09.

44 BAM $178-80$. 
movement, the Karaites. Men such as Yefet ben 'Eli (d. after 1006) espoused rational theology such as the Mu'tazilites had propounded in the Muslim sphere from the ninth century onward, and ditched the rabbinic notion of continuous revelation ('oral Torah') in favour of scripture, and Aramaic/Hebrew for the new world-language, Arabic. That exposed them to the latest currents in both Muslim and Christian thought, especially in Baghdad where the whole world flowed together. Until very recently the Karaites seemed obscure and peripheral, but thanks to improved accessibility of Russian libraries, with their deposits of Hebrew manuscripts, they are now an exciting new frontier in scholarship. It appears that their intellectual choices were more typical of late First Millennium Judaism than had been appreciated.

Far from attaining permanent, definitive form in the fifth to sixth centuries, then, Judaism and Christianity continued to evolve under and thanks to Islam. Not that the Islamicate world offered the only environment in which progress was possible, despite the insistence of some of its apologists that the Christian empire had corrupted its inheritance from the Greeks, which only Muslims were in a position to understand. ${ }^{45}$ The history of law in East Rome after Justinian's monumental codification is proof enough, if one considers Leo III's Ecloga (741) or the Basilics (c. 900), of the continued dynamism of this tradition too (even if in the caliphate Roman failed to compete with Qur'anic law). In more than just the Muslim perspective, then, the seventh century was a pivot not a break. I propose now to flesh out this approach to First Millennium continuities by looking at 'Golden Age' Baghdad, for a fuller sense of how it resumed and developed the First Millennium's stream of concepts. Despite its diversity of other faiths, there is no reason not to stay for a moment with its Jewish community, and particularly those Jews whose philosophical interests exposed them to intellectual intercourse with scholars from other traditions.

Jews had taken no serious interest in philosophy after the profoundly Hellenized exposition of scripture by Philo of Alexandria (d. 50 CE). ${ }^{46}$ The rabbis never alluded to Philo. But interest in philosophy began to revive in the ninth century (Dāwūd alMuqammaș) and was established in the tenth thanks especially to Saadia Gaon (d. 942), perhaps the figure most central to Abbasid Jewry's rapid evolution. As head of the Sūra' Academy, Saadia was fully trained in rabbinic tradition; but he was also well read in both Aristotle and the Platonizing thought of the first Arabic philosopher, Kindī (d.c. 870). Writing in Arabic (though often in Hebrew script), he defended oral Torah against the Karaites, but also demonstrated the compatibility of both Jewish scriptural commentary and rabbinic erudition with the authority of reason, as exemplified by the Greeks and by Muslim theological discourse, including Mu'tazilism. Saadia reveals a maturation in Jewish thought. At the end of the First Millennium, he and a few others were nudging Judaism toward the mainstream of

45 Gutas, Greek thought, Arabic culture (above, n. 32) 83-95.

46 This paragraph condenses BAM 180 -81, q.v. for bibliography. 
Arabic intellectual debate. Jewish philosophy did not disappear again as it had after Philo, but became a vigorous part of both the Latin and the Arabic thought worlds. One has only to think of the Aristotelianism of Maimonides (d. 1204)-one of the many reasons we talk about Arabic not Islamic philosophy. And it is noticeable that, whereas Jews played almost no part in translating philosophy from Greek into Arabic, they were prominent in its next transition, from Arabic to Latin.

In the closing years of the tenth century ${ }^{47}$ an Andalusian visitor to Baghdad recorded how he attended an assembly (majlis) of scholars where he met Sunnis and 'heretics' (presumably Shiites), Mazdeans, Jews and Christians, plus 'materialists' and 'atheists', by which he must have intended philosophers. One of the non-Muslims proposed disallowing appeal to the Qur'ān (or, one assumes, any other revealed scripture). 'Let us dispute with one another only on the basis of arguments from reason, and what observation and deduction will support.' Our Andalusian was shocked by this and avoided any more such assemblies. But there are signs that this style of arguing was not uncommon as a way of ensuring rational discussion all sides could participate in. The relative merits of logic, in other words Greek philosophy, versus grammar, that is to say the Qur'anic sciences aimed at elucidating the living word of God preserved in the Arabic scripture, were much debated. Among leading advocates of logic were some of the Christian philosophers so prominent on the tenthcentury Baghdadi scene, for example Fārābī's teacher Abū Bishr Mattā (d. 940) or his pupil Yahyyā ibn 'Adī (d. 974). They might also be its victims, as when one of Yahyyā's Christian pupils, Ibn Zur'a, was challenged as to why Christians invoke Father, Son, and Holy Spirit rather than Mind, Thinking, and Thought. ${ }^{48}$

There can be no mistaking the extraordinary diversity and intellectual interplay of Abbasid Baghdad, which goes some way towards justifying what may seem like over-attention to dhimmi communities in non-Muslim research. But the greatest monuments of Baghdadi scholarship in this era issued from the Sunni Muslim camp, in fact from a single individual already mentioned in passing, Țabarī, whose name reveals that he hailed from Iran, as did the great majority of Muslim scholars at this time. ${ }^{49}$ In Tabarī's day the Persian language (he himself used Arabic) was poised to enter the revival phase sealed by Ferdowsi's historical epic the Shahname, completed in 1010. And Tabarī’s awareness of the heroic tradition of Iranian

47 This paragraph condenses BAM 208-09, q.v. for bibliography, to which may be added: J. Scheiner and D. Janos (eds), The place to go: Contexts of learning in Baghdād, 750-1000 C.E. (Princeton 2014); Janos (ed.), Ideas in motion in Baghdad and beyond (above, n. 40). The Andalusian was Abū 'Abd Allāh al-Ḥumaydī, Jadhwat al-muqtabis [ed. M. ibn T. al-Tanjī (Cairo 1953)] 101-02 [tr. Griffith, Church in the shadow of the Mosque (above, n. 42) 64].

48 Ibn Zur'a, Maqāla fī'l-tathlīth [ed. P. Sbath, Vingt traités philosophiques et apologétiques d'auteurs arabes chrétiens du IX au XIV siècle (Cairo 1929)] pp. 10 -11 [tr. H. F. Thomson, Four treatises by Isā Ibn Zura, tenth century Jacobite Christian of Baghdad (diss. Columbia 1952)]. The allusion is to Aristotle, Metaphysica $\Lambda 9$.

49 S. F. Starr, Lost Enlightenment: Central Asia's Golden Age from the Arab conquest to Tamerlane (Princeton 2013). 
history and culture was no less intense than Ferdowsi's. He remains to this day our principle source for Sasanid history. His History of the prophets and kings deployed the succession of Iranian dynasts as the frame for pre-Islamic world-history, 'since after the Persians no nation except them has a continuous, unbroken history', not even the Jews. ${ }^{50}$ And his account of the caliphs of Islam draws on a mass of earlier traditions he had collected, as the hadīth scholar he was, during long research trips. Hadith, the sayings of the Prophet and his companions, was the foundation for both Qur'anic and historical scholarship in early Islam. Only when Tabarī approaches his own times does he achieve a more fluent narrative freed from the need to adduce strings of authorities and several accounts of the same events. Naturally, Tabari also deploys this traditionist style of writing in his Qur'ān commentary, his other major claim to fame and the overwhelmingly dominant specimen of its genre, canonical in the Sunni world. The accumulative type of research underlying both History and Commentary helps explain not only their immense length, but also the fact that Tabari was able to establish a solid reputation in a third field of learning, Islamic law, whose four mainline schools-Hanafis, Malikis, Shafi is and Hanbalis-were crystallizing at precisely this period, though they still had competitors, including one named after Tabarī himself.

Although Țabarī starts from Creation, his History focuses overwhelmingly on the period from the accession of the Sasanids in the 220s to 915 where he stops-a shorter First Millennium. I mentioned earlier the limitations of his geographical horizon in the West. These limitations were transcended, paradoxically, in an immensely briefer work, Elias of Nisibis's early-eleventh-century Chronicle, indebted to Țabarī among others. Elias, whose First Millennium time-frame I have already alluded to, exemplifies particularly well the effortless range of historical and cultural reference an educated Iraqi might dispose of (in contrast to, say, Constantinopolitan equivalents). ${ }^{51}$ His remit embraces the Sasanids, Rome and the caliphate; he presents his text in both Syriac and Arabic; he deploys hijri dating as soon as it becomes available; and he draws on Muslim as well as Christian predecessors.

A much fuller-indeed maximalist-sketch of the Iraqi mental horizon might be obtained in Baghdad itself by visiting the bookshops. One of the best, frequented by a coterie of intellectuals, belonged to one Ibn al-Nadìm, who inherited it from his father. Ibn al-Nadim had the idea of drawing up a list, or fihrist (a rare Persian word), of all the books he had himself examined or been told of by others. Completed in 987-88, the Fihrist is like a thematic bibliography, but occasionally shows signs of evolving into something more like an encyclopedia..$^{52}$ It aims to cover 'the books of

50 Al-Ṭabarī, Ta'rīkh al-rusul wa'l-mulūk [ed. M. J. de Goeje and others, Leiden 1879-1901] 1.148, 353 [English translation ed. E. Yarshater (Albany 1985-2007) 1.319, 2.133-34].

51 Cf. Fowden, 'War das erste Jahrtausend eine bedeutsame Periodisierung für die Zeitgenossen?' (above, n. 31).

52 Ibn al-Nadīm, Fihrist [ed. 1) R. Tajaddud (Tehran 1971); 2) A. Fu'ād (London 2009) (replaces Tajaddud); English translation (unreliable) ed. B. Dodge, New York 1970]; cf. article cited in previous note. 
all peoples, Arab and foreign, existing in the language of the Arabs' (1.1, p. 3; tr. 1). Ibn al-Nadim lists numerous translations from Greek, Syriac, Persian and Indian languages, and draws up, for example, specialized reading lists of Indian medical books in Arabic (the knowledge-circuit discussed earlier had not yet entirely lapsed). He includes modern authors, for example Saadia Gaon (1.1, p. 55; tr. 44) in 942. He opens the first of his ten books by surveying 'the languages of the peoples, Arab and foreign', by which he means scripts, starting with Arabic, then Syriac, Persian, Hebrew, Greek and a variety of others as remote as Latin (glimpsed on Frankish swords) and Chinese (seen on fans). Then he enumerates the scriptures of the Jews, Christians and Muslims. He draws on living tradition too: desiring an authoritative account of the Christian Bible, 'I asked Yūnus the priest, who was an excellent man' (1.1, p. 56; tr. 45).

The Fihrist goes on to deal with the Qur'anic sciences; grammarians; historians and genealogists; poetry; Muslim sects including various strands of the Shiism Ibn al-Nadīm himself espoused; eight law schools not just four, again in order to embrace the Shiite traditions; and then, in book 7, translations of Greek philosophy, mathematics, astronomy and medicine. Next come collections of fables and love stories from various languages, and books on magic; while book 9 addresses non-recognized religions like paganism, Manicheism and Buddhism, but oddly not Mazdaism even though the Fihrist is replete with Iranian materials and its author may have been an Iranian. There are notes on India and China (partly based on travellers' reports); and the closing book treats of alchemy. Conspicuous by their absence, though, from Ibn al-Nadim's taxonomy-perhaps they were written during the same years-are the Epistles of the Brethren of Purity, an anonymous circle of again Shiite scholars active in Bașra in the 970s and 980s. ${ }^{53}$ The Epistles convey a general and relatively comprehensive scientific, philosophical and religious worldview in non-technical language infused with religious values, without pushing back the frontiers of thought, but minutely classifying the branches of learning according to the Aristotelian model, though their emanationist vision of knowledge and reality is redolent of late Platonism. Beyond these Greek philosophical debts, the Epistles draw extensively on the whole First Millennium intellectual heritage, building a wide range of allusion to Babylonian, Iranian, Indian, Jewish, and Christian learning on a broad, albeit imaginatively deployed, bedrock of Qur'anic allusion. Their ideal man is

learned, accomplished, worthy, keen, pious and insightful...Persian by breeding, Arabian by faith, a pure monotheist [hanīf] by confession, Iraqi in culture, Hebrew in lore, Christian in man-

53 D. de Smet, 'Die Enzyklopädie der Ihwwān aș-Ṣafā' ', in U. Rudolph (ed.), Philosophie in der islamischen Welt 1: 8.-10. Jahrhundert (Basel 2012) 531-9, 551-4. 
ner, Damascene in devotion, Greek in science, Indian in discernment, Sufi in allusiveness of expression [ishārāt], regal in character, masterful in thought, and divine in awareness. ${ }^{54}$

The Epistles are not uncritical in their treatment of the various strands of thought they draw on, even the Qur'anic. But one's general impression is of a tolerantly eclectic approach to the whole spectrum of knowledge accessible to an educated tenthcentury Iraqi. Since Iraq was still at this time close to being the centre of the Eurasiatic world, the intellectual panorama offered by the Epistles takes in almost the whole First Millennium. One is particularly struck by the Brethren's tendency to treat the Jewish and Christian scriptures more or less on a par with the Qur'ān. Nevertheless, acquisition of this universal and comprehensive encyclopedia is to one single and undisputed end, namely the soul's salvation and its liberation from the physical world. And this is conceived of in a Muslim context: the culmination of human experience is Islam. A roughly contemporary and again anonymous compilation, this time in Syriac, and known as The book of the cause of all causes, likewise mobilizes encyclopedic knowledge in the service of a 'universal religion' designed for all peoples, but this time necessarily Christocentric. ${ }^{55}$ Sectarian allegiances remained undeniably strong, alongside an awareness of the congruence of notable traditions both human and divine.

There is an obvious attractiveness to ending this survey of First Millennium empires and conceptual currents with Baghdad's much-vaunted 'Golden Age', in which scholars and their patrons brought together so much that was vital in the worlds Sasanid and Roman emperors and Muslim caliphs had ruled over. Abbasid Baghdad witnessed the maturation of many features we now see as characteristic of 'classical' and indeed modern Islam. The tenth century is the point when the Qur'anic sciences, law, historiography, and indeed the schism between Sunnis and Shiites, all gained a profile still recognizable today. Yet we must also heed Thomas Bauer's recent warning that over-emphasizing these achievements plays into the hands of those who wish to see the next millennium, up to our own times, as a story of sterility and decline in the Muslim world. ${ }^{56}$

Baghdad was indeed at the end of the tenth century the scene of bloody confrontations between Sunnis and Shiites. The Abbasid caliph had become a figurehead controlled by Iranian Shiite generals, the Buyids. The bottom was falling out of the Iraqi economy and the commercial middle class was moving to Fatimid Cairo,

54 Rasā’il Ikhwān al-Ṣafā' 22.42 [ed. 1) B. Bustānī (Beirut 1957) 2.376; 2) (with English translation, here slightly adjusted) L.E. Goodman and R. McGregor, Epistles of the Brethren of Purity: The case of the animals versus Man before the King of the Jinn (Oxford 2009) rv^/313-4].

55 G. J. Reinink, 'Communal identity and the systematization of knowledge in the Syriac "Cause of all causes" ', in P. Binkley (ed.), Pre-modern encyclopaedic texts (Leiden 1997) 275-88.

56 T. Bauer, Die Kultur der Ambiguität: Eine andere Geschichte des Islams (Berlin 2011) 53, 58 -59, 161, $296-97$. 
which proclaimed itself the capital of a parallel caliphate. The Jewish academies were in decline, and their leading authorities would soon emigrate to new centres in North Africa and Spain. Ibn Sīnā (Avicenna) (c.970 -1037), who approached philosophical maturity around the turn of the millennium, never visited Baghdad. Instead, he was a characteristic product of the emergent 'Islamic Commonwealth' of autonomous states (such as those presided over by the Buyids and Fatimids) competing with each other in-among other things-offering asylum and patronage to wandering scholars. Ibn Sīnā passed beyond Fārābī’s dedication to the by now millennium-old Alexandrian/Aristotelian commentary tradition, and constructed a personal synthesis, reworking Aristotle and preparing the ground for the Ash'arite compromise between Qur'ān and Prophetic tradition (manifest in hadìth) on the one hand and a moderate appeal to rationalism (as in $\mathrm{Mu}^{\prime}$ tazilism) on the other. In his later works, Ibn Sīnā spoke of his ‘Eastern’ philosophy, honouring his native Khurāsān in contradistinction to Baghdad and Alexandria. That and, looking forward, his huge influence across many centuries in the Islamic world and in Europe, make his career an appropriate symbolic cut-off for the First Millennium-but by no means a symptom of decline.

In his Autobiography, Ibn Sīnā recalls how even as a youth he argued against the Isma'ili ideas debated in his father's household. ${ }^{57}$ This dynamic variant of Shiism fostered missionary activity across the Muslim world. One proof of the Ismailis' catholic tastes was their enthusiasm for the Brethren of Purity, whose Epistles would not otherwise have survived. It is likewise thanks to Isma ili scribal traditions and admirably preserved libraries that scholars have recently been able to reconstruct the teachings of one of their leading missionaries, Abū Ya'qūb al-Sijistānī (d.c. 971), a restless spirit who pushed as hard at the imported Greek philosophical tradition to bring out its Platonist as well as Aristotelian aspects, as he did at the inherited Muslim tradition to propagate not just what he conceived to be its inherent rationalism (as did the philosophers), but also the imami belief in continuous revelation of esoteric truths. ${ }^{58}$ That the Fatimids were Isma'ilis (however majority-Sunni their subjects) ensured this remarkable movement a firm base from which to propagate itself so widely that it has survived until now, offering a distinctive model of Islam remote from the well-known stereotypes.

At the present political and cultural conjuncture, proposing a new historical periodization designed to bring late Antiquity and early Islam together in a single narrative pivoted on the Qur'ān and Muhammad will strike some as perverse. It nevertheless has obvious pay-offs in the scholarly sphere, by sensitizing students to neglected aspects of late Antiquity that help contextualize Islam, such as Iran first

57 Ibn Sīnā and Abū 'Ubayd al-Jūzjānī, Sìrat al-shaykh al-ra'īs [ed. and tr. W. E. Gohlmann, The Life of Ibn Sina (Albany, NY 1974)] 18-20; and cf. translation by D. Gutas, Avicenna and the Aristotelian tradition: Introduction to reading Avicenna's philosophical works (Leiden 2014²) 12-13.

58 P. E. Walker, Early philosophical Shïsm: The Ismaili Neoplatonism of Abū Ya'qūb al-Sijistānī (Cambridge 1993); id., Abu Ya'qūb al-Sijistānī: Intellectual missionary (London 1996). 
and foremost; Arabia, our understanding of which is being revolutionized by epigraphy; and post-Chalcedonian patristics, especially the Syriac world. The monarchical systems developed by 'the world's two eyes' are better appreciated in the light of the caliphate's difficulty articulating the prophetic aspect of its mission, and its resort to the Sasanid model of kingship..$^{59}$ The assumption of massive urban decline in the late antique East can only be effectively challenged on the basis of Umayyad and early Abbasid archaeology. There is also the need to integrate certain well-tilled but isolated fields: not just legal studies and medicine, which I have passed over almost in silence, but also rabbinics which is far more directly relevant to the origins of Islam. But it is in the public sphere that the First Millennium is destined to have most impact. The emergence of a European Islam is now fully under way. It is subject to obvious and dangerous pressures, from both within and without, toward ghettoization. If such a negative development is to be avoided, a first step is to develop a historical narrative that brings out, not necessarily 'shared values', but a shared history, and the independent validity and interest of the eastern highway out of Antiquity. Study of the First Millennium is a step in this direction, enabling us to appreciate better the interrelations of the scriptural monotheisms, the enduring influence and interactions of Iran, Judaea, Greece and Rome, and the embeddedness of Islam in the late antique field of empires and its stream of concepts.

59 D. G. Tor, 'The long shadow of pre-Islamic Iranian rulership: Antagonism or assimilation', in T. Bernheimer and A. Silverstein (eds), Late Antiquity: Eastern perspectives (Oxford 2012) 145-63. The objections to this thesis in J. Lassner and M. Bonner, Islam in the Middle Ages: The origins and shaping of classical Islamic civilization (Santa Barbara, CA 2010) 149-52, focus exclusively on the debate about the architectural inspiration behind the new city of Baghdad. 